\title{
A Review of Women's Entrepreneurship in Vietnam Taking into Account Socio-Cultural Norms and the Institutional Ecosystem
}

\author{
Nguyen Hoang Anh \\ Foreign Trade University (FTU), Vietnam \\ nguyenhoanganh@ftu.edu.vn
}

This paper reviews the status quo of women entrepreneurs considering the impact of socio-cultural norms and institutions on women's entrepreneurship in Vietnam. First, we discuss relevant literature and provide an overview of women's entrepreneurship in Vietnam. We analyse the impact of socio-cultural norms and institutional landscape on motivation to start and do business of Vietnamese women and identify critical facilitators and barriers that currently affect women entrepreneurs in Vietnam. Finally, we propose recommendations for changes to traditions and norms, and improvement of government policies in supporting women entrepreneurship in Vietnam

Research for this paper was funded by the Swiss State Secretariat for Economic Affairs under the SECO / WTI Academic Cooperation Project, based at the World Trade Institute of the University of Bern, Switzerland.

SECO working papers are preliminary documents posted on the WTI website (www.wti.org) and widely circulated to stimulate discussion and critical comment. These papers have not been formally edited. Citations should refer to a "SECO / WTI Academic Cooperation Project" paper with appropriate reference made to the author(s). 


\title{
A review of women's entrepreneurship in Vietnam taking into account socio- cultural norms and the institutional ecosystem
}

\author{
Nguyen Hoang Anh \\ Hoang Truong Giang \\ Du Vu Hoang Tuan \\ Hoang Bao Tram
}

\begin{abstract}
This paper reviews the status quo of women entrepreneurs considering the impact of socio-cultural norms and institutions on women's entrepreneurship in Vietnam. First, we discuss relevant literature and provide an overview of women's entrepreneurship in Vietnam. We analyse the impact of socio-cultural norms and institutional landscape on motivation to start and do business of Vietnamese women and identify critical facilitators and barriers that currently affect women entrepreneurs in Vietnam. Finally, we propose recommendations for changes to traditions and norms, and improvement of government policies in supporting women entrepreneurship in Vietnam.
\end{abstract}

Keywords: women entrepreneurs, socio-cultural norms, traditions, institutional ecosystem, Vietnam

\section{Introduction}

Since the economic reform (Doimoi) in 1986, Vietnam has achieved an outstanding economic growth. During the period of 1990-2010, the economy of Vietnam experienced an annual average rate of 7.3 percent even counting the recent economic crisis (World Bank, 2011b). It is recognized that a blooming market of private enterprises has contributed significantly to this rapid growth. It is generally recognised that Vietnamese women are increasingly involving in entrepreneurial activities and making greater contribution to the development of the economy. According to an estimation of International Labour Organisation (ILO, 2011), about 25 percent of Vietnamese business owners are women.

Women entrepreneurs and women owned companies contributed considerably to the job creation and economic development of Vietnam. Although women have gained better economic opportunities, their productive potential is underutilized due to cultural values and 
an unfavourable business environment. The traditions expect that a woman's role is to taking care of family and doing housework while men are relied upon to provide the main source of income for the household. Women entrepreneurs face the challenges of equal access to resources, finance and business training.

Being aware of these barriers, the Vietnamese government has committed itself to promoting gender equality and women's empowerment over the past decade. In 2006, the Vietnamese Parliament approved the Gender Equality Law which aimed to improve women's roles in society, particularly in business. Support for women entrepreneurship is also found in other laws and regulations. Though progress has been made, little is known about the cultural and institutional impacts on women entrepreneurship in Vietnam. To address this issue, our paper aim to provide understandings into the current status of women entrepreneurship in Vietnam, to identify barriers and difficulties they face in doing business, and to analyse the traditions and regulations that might have impacts on women entrepreneurship in Vietnam. Furthermore, we propose implications which may help policy makers build a support system for the development of women entrepreneurship and suggest some significant topics for further studies.

The paper will be organised as follows. Section 1 discusses the relevant literature of and provides an overview of women entrepreneurship in Vietnam. Section 2 and Section 3 provides a deep analysis of traditions and regulations issues that might have impacts on women entrepreneurship in Vietnam. Finally, in Section 4, the paper concludes with implications and recommendations for tradition changes and regulatory facilitation in support for Vietnamese women entrepreneurship.

\section{Overview of women entrepreneurship in Vietnam}

\section{The concept of women entrepreneurship}

Entrepreneurs have been defined in various ways, but most definitions suggest they are people who develop new and innovative ideas for products, business models, or markets (Nijssen, 2014). Accordingly, entrepreneurship is basically a creative activity in which entrepreneurs perceive opportunities to innovate (Nijssen, 2014; Raven \& Le, 2015). When the literature distinguishes between different types of entrepreneurship, it uses a wide variety of terms, amongst them are opportunity and necessity entrepreneurship. The former term is linked to the identification of good business opportunities, while the latter one is related to 
the lack of better job opportunities (Fuentelsaz et al., 2015). Even though both types refer to new entrepreneurial activities, their effects on development and economic growth are clearly different. Acs and Varga (2005) identified that necessity entrepreneurship does not affect economic development, and opportunity entrepreneurship has a positive and significant effect.

In recent years, a number of developing countries, including Vietnam, have enacted market-oriented economic reforms aimed at developing their markets to promote entrepreneurship and private enterprise (Hoskisson, Eden, Lau, \& Wright, 2000). As a result of these reforms, these countries are becoming major economic forces in the world, and entrepreneurship (including the start-up and growth of formal businesses) has been credited with playing 'a key role in this development' (Bruton, Ahlstrom, \& Obloj, 2008). Noting the growing importance of entrepreneurship in developing countries, and citing a paucity of research on the topic, scholars have called for more research into women entrepreneurship in developing countries (Chari \& Dixit 2015) and Vietnam is a typical country for this topic due to its fast growth.

Since women entrepreneurship is considered as a source of economic development, innovation and growth, the study of factors that influence rates of women in creating new companies has become an important issue on the agendas of economists, researchers and politicians in most countries (Rubio-Bañón, \& Esteban-Lloret, 2015). Understanding the role played by the cultural and institutional factors in entrepreneurship is significant to comprehend how to encourage culture and entrepreneurial behaviour of women entrepreneurs.

\section{Contribution of women entrepreneurship to Vietnamese economy}

In Vietnam, the 1986's Economic Renovation ("Doi Moi") marked the revival and resurrection of the private entrepreneurship, which has since become "the most important driver of the omnipresent growth of the economy" (Vuong \& Tran, 2009, p. 57). Women entrepreneurship has been particularly noticed, as it can provide greater income, promote autonomy and boost female empowerment, especially in the age when gender gap in Vietnam is still broad (World Bank, 2011a).

Current demographic and labour data indicate that women have contributed significantly to the economic development of Vietnam. Data from the World Bank's World 
Development Indicators (WDI, 2012) during the period 1996-2010 reveals some gender differences in terms of population, levels of education, wages, and labour force participation. Although the female population in Vietnam is larger than the male population, the female labour force is smaller. While the gap between males and females in the labour force has narrowed, there are still more males working. Males have higher literacy rates than females and while women have made significant increases in their education, school enrolments for males are still slightly higher than for females (WDI, 2012). However, there are more women working in the agriculture and service sectors than men. Female self-employment is also higher than male self-employment. Last, the unemployment rate is the same at 2 percent, but, there are more male wage and salaried workers than female wage and salaried workers (WDI, 2012). However, there has been no empirical research to identify the rate of opportunity and necessity entrepreneurship in Vietnam.

The issue of gender and employment is critical to achieve poverty reduction and contribution of women to economic growth. In a Joint Country Assessment, the International Labour Organization and the Ministry of Labour, Invalids and Social Affairs of Vietnam confirmed that creating more and better employment opportunities (ILO/MOLISA, 2010) is crucial to the establishment of sustained escape paths out of poverty and vulnerability.

The following table presents data concerning the percentage of employed males and females in Vietnam who take part in entrepreneurial activity for the years 2007, 2009, 2011, and 2012.

Table 1: A comparison between employed population, male and female, Aged 15 and over in Vietnam

\begin{tabular}{|c|c|c|c|c|c|c|}
\hline \multirow[b]{2}{*}{ Year } & \multicolumn{3}{|c|}{ Female } & \multicolumn{3}{|c|}{ Male } \\
\hline & Total & Employers & $\begin{array}{c}\text { Own- } \\
\text { Account } \\
\text { Workers }\end{array}$ & Total & Employers & $\begin{array}{c}\text { Own- } \\
\text { Account } \\
\text { Workers }\end{array}$ \\
\hline 2007 & 61.3 & 2.7 & 58.6 & 52.4 & 3.8 & 48.6 \\
\hline 2009 & 50.1 & 3.2 & 46.9 & 48.9 & 6.3 & 42.6 \\
\hline
\end{tabular}




\begin{tabular}{|c|c|c|c|c|c|c|}
\hline 2011 & 46.3 & 1.8 & 44.5 & 47.3 & 3.9 & 43.4 \\
\hline 2012 & 47.8 & 1.7 & 46.1 & 47.9 & 3.7 & 44.2 \\
\hline Average & $\mathbf{5 1 . 3 5}$ & 2.35 & 49.03 & $\mathbf{4 9 . 1 1}$ & 4.43 & 44.70 \\
\hline
\end{tabular}

Source: Vietnam Labour Force Survey, 2011 and 2012

Overall, the table illustrates that employed female entrepreneurs had a somehow similar percentage to employed males. In particular, the percentage of female entrepreneurs reached an average of $51.35 \%$, compared to a percentage of $49.11 \%$ of male entrepreneurs. Notably, women were more vulnerable to economic shock than their male counterparts. In fact, before the wake of the global financial and economic crisis, women took up $61.3 \%$ of entrepreneurship, nearly $10 \%$ higher than that of men in 2007 . While both data saw a decline over the period of $2007-2009$, the percentage of female entrepreneurs experienced a surge by $11.2 \%$, which was nearly three times higher than corresponding data for men. Also, it should be noted that there is a difference between the two definitions "own-account workers" and "employers". The first one refers to the situation where one is self-employed with no regular employees hired (Avin \& Kinney, 2014). The second one, however, is associated with employees. Regarding the breakdown of entrepreneurs into these two types of workers, it can be seen that they underwent contradictory trends. While the proportion of own-account workers tended to fall throughout the period, the percentage of employers rose from 2007 to 2009. Nevertheless, both failed to match their levels before the recession started. In addition, over the mentioned period, the majority of female entrepreneurs were linked to own-account workers, unlike their male counterparts who were more likely to be employers. As a consequence, this implies higher vulnerability for female entrepreneurs, as well as there is likelihood that these women-run businesses would be smaller and more vulnerable than male-owned firms.

The Global Entrepreneurship Monitor (GEM) project was initiated in 1999 with the intention of expanding knowledge about entrepreneurship across the world. In 2013, it issued its first report on Vietnam based on a survey of 2000 Vietnamese adults aged 18 to 64 (GEM, 2013). They provided data by gender for "Total Early-Stage Entrepreneurial Activity" (business start-ups plus businesses in operation for more than 3 months but less than 3 years and a half) 
and for "Established Businesses" (in operation for more than 3 years and a half). Since this was GEM's first survey covering Vietnam, only data for 2013 are available (see Table 2). Table 2 reports in the first column of figures that $13.9 \%$ of females surveyed were "early-stage entrepreneurs" while $16.1 \%$ headed "established businesses." Table 2 uses total persons (male or female) surveyed as the denominator; total persons surveyed could be employed, but also unemployed or not participating in the labour market. It is indicated that the percentages of females surveyed that were identified as entrepreneurs were very close to those of males, particularly in established businesses ( $16.1 \%$ of women surveyed operated established businesses versus $16.6 \%$ of men surveyed) (GEM, 2013).

Table 2: Male and female entrepreneurship in Vietnam and "factor-driven economies" in 2013

\begin{tabular}{|l|c|c|}
\hline & VIETNAM & FACTOR-DRIVEN ECONOMIES \\
\hline $\begin{array}{l}\text { Female early-stage } \\
\text { entrepreneurial activity } \\
\text { (\% of adult females surveyed) }\end{array}$ & 13.9 & 19.80 \\
\hline $\begin{array}{l}\text { Male early-stage } \\
\text { entrepreneurial activity } \\
\text { (\% of adult males surveyed) }\end{array}$ & 16.8 & 22.33 \\
\hline $\begin{array}{l}\text { Female established businesses } \\
\text { (\% of adult females surveyed) }\end{array}$ & 16.1 & 12.10 \\
\hline $\begin{array}{l}\text { Male established businesses } \\
\text { (\% of adult males surveyed) }\end{array}$ & 16.6 & 14.60 \\
\hline
\end{tabular}

Source: Global Entrepreneurship Monitor Vietnam Report 2013, p.35

The GEM survey also provides a basis for comparing female and male entrepreneurship in Vietnam in 2013 to that in other countries. One way is to compare rates of entrepreneurship in Vietnam to rates for comparable economies which GEM calls "factordriven economies" (GEM, 2013). These are low-income economies with relatively high shares of primary product exports such as Vietnam, the Philippines, India, and several countries in sub-Saharan Africa. Comparing the last column in Table 2 with the figures for Vietnam, the percentages of both female and male early stage entrepreneurs are lower in Vietnam than in "factor-driven economies." In contrast, the percentages of surveyed females and males in 
Vietnam operating established businesses are higher than those in the comparable countries. The GEM report attributes the lower rate of new business establishment in Vietnam to its slower recovery from the 2008-2009 recession than other countries (GEM, 2013).

\section{Characteristics of Vietnamese Female Entrepreneurs}

\section{Educational level}

In 2006, the general population literacy rate in Vietnam is at $93 \%$ with female literacy rate at $90 \%$, only six percentage points lower than men (96\%) (Tien, 2010). This is a remarkable achievement from 1943 literacy rates where approximately 95\% of the population and $98 \%$ of Vietnamese women could neither read nor write (Bunck, 1997).

However, it is evident that Vietnamese women are short of educational and professional training, particularly on-the-job training and business administration skills. "Women have less education and training in competencies such as management, communication and decision making skills" (Vietnam Women Entrepreneurs Council 2007, p. 28). Pursuant to the survey of UNIDO (2010), it is suggested that male entrepreneurs were significantly more academically qualified than female counterparts. This means Vietnamese male entrepreneurs have more important academic knowledge to start up business than Vietnamese females (UNIDO, 2010).

\section{Geographic Allocation}

It can be seen that female entrepreneurs were mostly in the rural regions, with over a half of total female employed workers, $10 \%$ higher than the proportion of those in urban areas. Among them, the majority were own-account workers, rather than employers. Figure 2 shows that $51.1 \%$ of total female employed workers working in the rural areas included $50.1 \%$ of own-account workers and merely $1 \%$ of employers. A similar pattern occurred within female entrepreneurs in urban areas. This implies female-owned businesses in urban areas are probably much larger compared to those run by females in the rural regions.

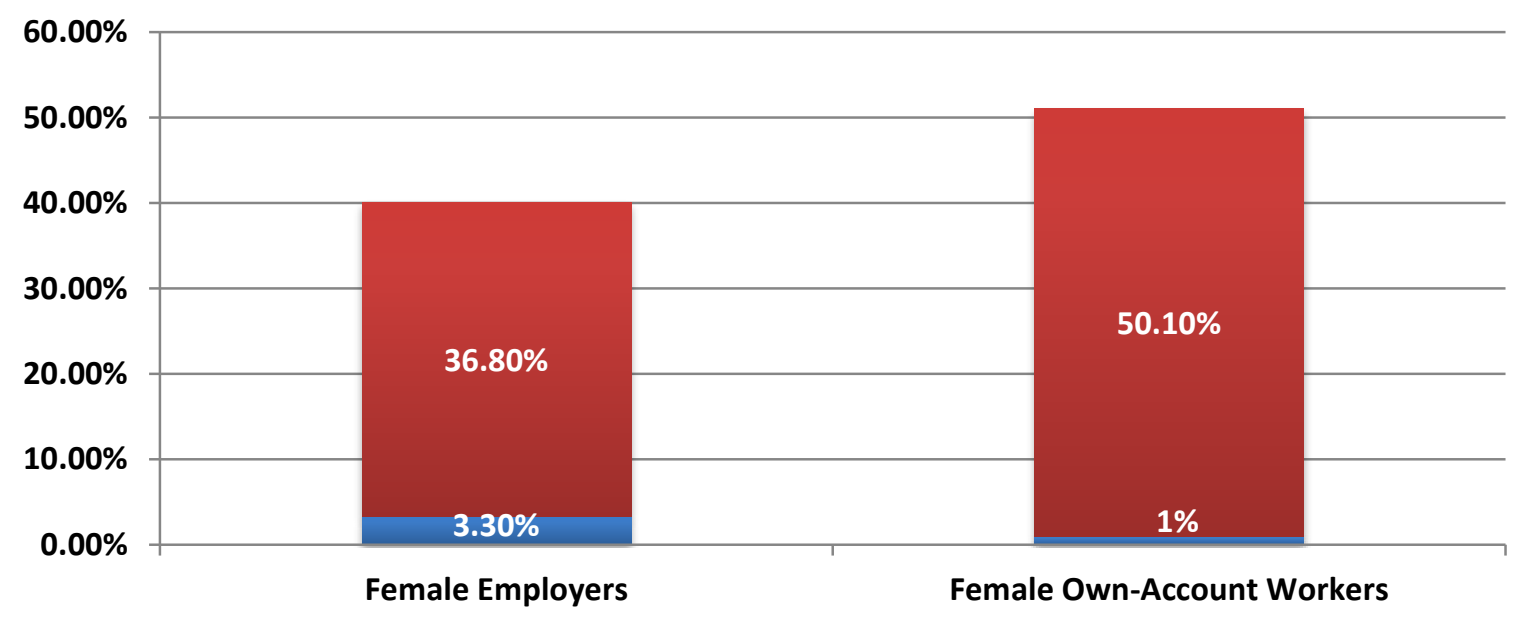


Figure 2: Women entrepreneurship Distribution in Rural and Urban Areas, 2012

Source: Vietnam Labour Force Survey, 2012

Regarding distribution of entrepreneurs across Vietnam, it is apparent that they tended to execute entrepreneurial activities in more populated regions, namely Red River Delta or Mekong River Delta, all of which had a percentage of at least $50 \%$ of total female employed workers. Particularly, Hanoi and Ho Chi Minh City, the two largest metropolitan of the country, accounted for a significantly high percentage of female entrepreneurs with over two-thirds of total female workers altogether (see Figure 3).

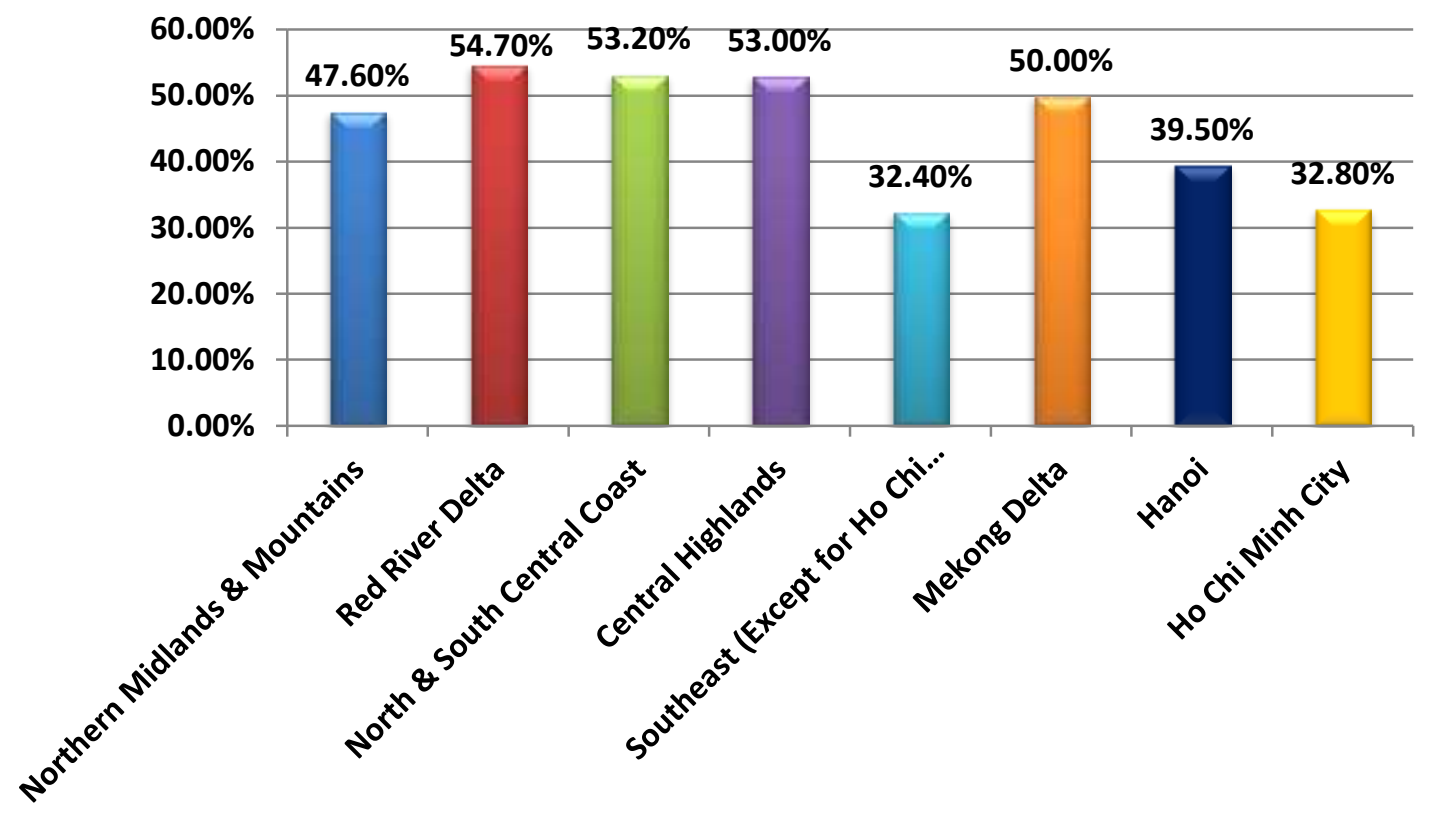

Figure 3: Women entrepreneurship by Region, 2012

Source: Vietnam Labour Force Survey, 2012

The 2009 National Population Census (Central Population and Housing Census Steering Committee, 2010) indicated that women accounted for 54 precents of the rural population in Vietnam. Similarly, the Vietnam Women Entrepreneurs Council (VWEC, 2007) reported that over 60 percent of Vietnamese women worked in agriculture in 2002 and Hang (2008) found that 76 percent of female workers in Vietnam were concentrated in agriculture, forestry and fish farming. The urbanization and rural mechanization process in Vietnam has created dramatic changes in rural areas, leading to changes in the livelihoods of rural women. The most significant of these changes has been the conversion of large amounts of farming land to 
industrial zones, tourism sites or new urban areas. This, in turn, has led a significant increase in the rate of unemployment in rural Vietnam (Hoang, 2010). As a result, a growing number of males and a large proportion of the youth population have left their families to earn a living in urban areas or industrial zones. This trend in migration has exposed rural families and rural communities to substantial structural changes. It has resulted in "feminised agriculture" (that is, women are in charge of almost all agricultural production), an "aging rural sector" (that is, the majority of villagers are now middle-aged or elderly), and "women household heads" (that is, the males have migrated to urban areas) (Hoang, 2010; Thanh et al., 2005).

\section{The impacts of Socio-cultural norms on women's entrepreneurship}

\section{Women's position in Vietnamese society}

This section provides a short background on the history of Vietnamese traditions with focus on the social roles of women. We also analyse the impacts of these traditions on Vietnamese women's perceptions in starting and running a business

The culture of Viet Nam is one of the oldest cultures in the Pacific Ocean Region. Vietnamese culture has evolved a number of characteristics more similar to its East Asian neighbours but different from other countries in Southeast Asia that have been considerably more influenced by the Indian culture. For example, the Vietnamese family is modelled after Confucian principles which are structured along male lines (Kibria, 1990). Women's subordinate position relative to male members of the family gives the men freedom to make important decisions for the family (Luke et al., 2007). On the other hand, Vietnamese women are expected to ensure family harmony by complying with their husband and in-law's wishes, and by being passive and hardworking (Luke et al., 2007).

In earlier times, Vietnamese women were married off early and tended to move in with the husband's household. A married woman has minimal stature in the family until she bears sons; older women tend to receive higher status and more power. Household heads who represent the household in extra-family affairs are mostly men, in conformity with Confucian tradition (Hirschman \& Loi, 1996). Changes in family composition that lead to female family headship rarely occur, but socio-economic demands in urban areas have recently altered traditional Confucian family headship notions. 
In 1979, Viet Nam became one of the first countries to adopt the Convention on the Elimination of All forms of Discrimination against Women (CEDAW). Since then, the country has taken bold policy changes towards improving the situation of Vietnamese women relative to men; including the publication of the 2004 "Guidance for the integration of gender in policy planning and implementation" and the more recent Law on Gender Equality in 2007 (Tien, 2010). The state's efforts have led to increased number of women involved in politics, commerce, education, finance, and healthcare (Thi, 1995).

\section{Socio-cultural factors influencing women doing business}

\section{Family support}

Family support is considered one of the most important factors impacting women in starting a business, whether for financial or network support, or as unpaid manpower (UNIDO, 2010). For both male and female entrepreneurs across three regions (North, Central and South), family support received during business start-up was overwhelmingly affirmative (on average, $81 \%$ ), with very little resistance from family and relatives For matters related to business, significantly more women than men ( $77 \%$ versus $51 \%$ respectively) turn to family for guidance regarding important business decisions (Hoang et al., 2013). Vietnamese women's decision to ask family members for guidance are shaped by a variety of values in their lives, including educational attainment, culture, their status in the family, and their overall socioeconomic position. The same argument holds true for Vietnamese men although their actions are opposite that of women's.

\section{Age}

Over $73 \%$ of female entrepreneurs believed age was not a negative factor to start and continue businesses (Hoang et al., 2013). The combination of youth and gender was said to create difficulties for women entrepreneurs in establishing relationships with suppliers and clients due to Confucian legacy in Viet Nam (International Finance Corporation, 2007).

\section{Gender}

The majority of female entrepreneurs in all three regions across Vietnam cited gender as a significant factor influencing the ease of business start-up. Table 3 shows the result of the survey which reflects the difficulties for Vietnamese women in start-up and continuation, controlled for type of enterprise. 
Across regions, female entrepreneurs from the Central and South reported more gender-related obstacles to running a business as compared to female counterparts in the North, reflecting on business network development and expansion and the ability to work with authorities. In terms of females leading different types of business, namely household, sole proprietorship, Limited Liability Company, cooperative and joint stock company, the latter of which saw the most impact of gender-related difficulties in business start-up and development with approximately $70 \%$ of respondents (Hoang et al., 2013).

Table 3: Difficulties in start-up and continuation, controlled for type of enterprise

\begin{tabular}{|l|c|c|c|}
\hline \multirow{2}{*}{ Type of enterprise } & \multicolumn{2}{|c|}{$\begin{array}{c}\text { Do you think being female made it more } \\
\text { difficult for you to start and continue your } \\
\text { business? }\end{array}$} & \\
\cline { 2 - 4 } & \multicolumn{2}{|c|}{ More difficult } & Easier \\
\hline Household & $3(60 \%)$ & $2(40 \%)$ & $5(100 \%)$ \\
\hline Sole proprietorship & $19(56 \%)$ & $15(44 \%)$ & $34(100 \%)$ \\
\hline Limited Liability company & $59(55 \%)$ & $48(45 \%)$ & $107(100 \%)$ \\
\hline Joint Stock company & $44(70 \%)$ & $19(30 \%)$ & $63(100 \%)$ \\
\hline Cooperative & $2(100 \%)$ & 0 & $211(100 \%)$ \\
\hline Total & $127(60 \%)$ & $84(40 \%)$ & $2(100 \%)$ \\
\hline
\end{tabular}

Source: Hoang et al. (2013). Note: Data does add up to total population because some respondents provided no answer.

\section{The impacts of institutions on women entrepreneurship}

This section provides an overview of legal framework that has impacts on women entrepreneurship in Vietnam. An analysis of laws and regulations influencing the business environment for Vietnamese women entrepreneurs that have been undergoing major policy changes recently will also be presented. 


\subsection{Legal Framework}

According to UNIDO (2010), institutions have a profound effect on not only the macroeconomy but also the micro one. Whether in the form of social perceptions or traditional values, for instance, institutions include socio-political dimensions as a means of assessing economic efficiency in both macro and micro level. As a consequence, it is utilised as a tool for the performance evaluation of female entrepreneurs. Vietnam has gradually developed its legal framework on gender equality in general and women entrepreneurship in particular.

The Constitution $(1982,2013)$ guarantees equal rights of both genders under the national law system. The Government of Vietnam is to be applauded for their efforts to guarantee and promote gender equity. These efforts are clearly expressed through the Constitution of Vietnam since its very beginning. An article in the 1946 Constitution reads: "All citizens of Vietnam, regardless of their sex and gender, share equal rights in all aspects of political, economic, cultural and social life". The issue has been reinforced through the national Constitution of 1959, 1980 and 1992. To bring this philosophy into practice, the Government has issued a series of decrees and programs focused in specific thematic areas.

The Gender Equality Law (2006) creates a regulatory framework for women to determine their rights to equal representation in all facets of life. Its purpose is to change the discriminatory perception toward women of the public. This law is guided by the Resolution 11-NQ/TW (27/04/2007), Resolution No. 57 dated 01/12/2009 and Decree 48 dated 19/05/2009.

The Enterprise Law (2014) provides a legal foundation for the establishment, organisation and operation of enterprises from different sectors of the economy. This law is supported by Decree 88, Decree 56, Circular 05 and Circular 03.

The Investment Law (2014) provides a framework for investment activities of all domestic and foreign investors operating in and outside Vietnam. Decree 103 supports this Law.

The Land Law $(1993,2013)$ created a real estate market and prompted a sweeping distribution program, permitting land transactions and legal titles for the first time in Vietnam. Although gender-neutral, the 1993 law seemed to benefit men more than women as the men received a larger portion of the Land Use Rights Certificates, with only 10 to 12 percent issued 
in women's names. The 2013 Land Law corrected some of the gender inequalities by requiring Land Use Rights Certificates to record the names of both spouses, as opposed to only the head of the household.

Government Plan of Action for Women's Affairs in the Country's Era of Industrialisation and Modernisation by 2020 (adopted in 2009) provides a detailed description of equality for men and women in all fields.

The National Strategy on Gender Equality 2011 - 2020 and the National Programme on Gender Equality 2011 - 2015 focuses on consolidating women leadership at administrative and legislative levels, along with the preparation for the 2016 elections. They stress the essential role of gender equality for the development of the society and economy of Vietnam. Some of the targets of these two are: at least $25 \%$ of positions in Party Committees will be acquired by women in the next term $(2016-2020)$ and at least $35 \%$ female representatives in the National Assembly and political levels by 2016.

\subsection{Impacts of contemporary Laws on women entrepreneurship in Vietnam}

In this section, a certain number of Vietnamese Laws and Decrees, which have been released and implemented, will be assessed in terms of their compatibility with the Law on Gender Equality. In fact, most Laws and Decrees conform to and assist the stipulations of the Law on Gender Equality. Nonetheless, there are still enough room for the improvement of these Laws and Decrees.

\section{Laws}

The economic potential of women has been recognized by the Vietnamese Government. Central Party Resolution No. 11 paved the way for the creation of the National Action Plan for Women 2008-2010. The Law providing for Gender Equality (No. 73/2006/QH11) was enacted by Vietnamese Parliament and then the government issued several decrees supporting, among others: mainstreaming of gender equality into legal normative documents (No. 48/2009/ND-CP), implementation of articles under the Gender Equality Law (No. 70/2008/ND-CP) and handling of administrative violations of gender equality (No. 55/2009/ND-CP). Also, the decree that supports the development of small and medium-sized enterprises and prioritises women-owned enterprises and female labourintensive SMEs (No. 56/2009/ND-CP) was recently reviewed and reissued. 
Both the Enterprise Law (2014) and Investment Law (2014), in general, conform to the Gender Equality Law (2006) to a large extent. However, they do not refer particularly to women in entrepreneurial activity. The positive aspect is that while most of the wording in both law do not specify male or female, the interpretation and implementation of the laws into practice can be applied for both genders. Besides, the utilisation of gender-neutral terms when it comes to entrepreneurs or investors implies the recognising of equal capabilities of men and women in starting, running and doing business. For instance, the Investment Law draws on non-discrimination principle when specifying the rights of investors to gain access and use public services in Article 19. Nevertheless, some articles can cause difficulty for women in entrepreneurship. One example is that the Enterprise Law permits small-scale family-run businesses to formalise business activities that began before the enactment of that Law (Article 270), but it does not specifically mention women entrepreneurs.

In regard to the issue of women equal access to property rights, Article 95 of the 2013 Land Law certifies that: "Where the land use right is a mutual asset of a wife and husband, the certificate of land use right must state the full names of both husband and wife. Where the land user of one parcel of land comprises a number of individuals, family households and organizations, a certificate of land use right shall be issued to each individual, family household and organization being a land co-user." The Land Law 2013 has made a significant progress in supporting land ownership of women. This facilitates the procedure for women in seeking financial assistance from banks and credit funds to start-up their own businesses.

Similarly, the Marriage and Family Law of 2000, Article 27 clearly states that "Common property of husband and wife includes property created by husband and wife, incomes generated from labour, production and business activities and other lawful incomes of husband and wife during the marriage period; property jointly inherited or given to both, and other property agreed upon by husband and wife as common property. The land use right obtained by husband and wife after their marriage is their common property.... Where a property under the common ownership of husband and wife is required by law to be registered for ownership, names of both husband and wife must be inscribed in the ownership certificate thereof."

The Government efforts have significantly improved gender equity in Vietnam during last decade. However, due to a number of reasons as presented in the following sections, a 
distinct gender difference still exists in practice. Surveys conducted by Action Aid (2008), the World Bank (2008), VARHS (2010) and UNDP (2006) all show, for example, that the percentage of women's names in the Land use certificates occupies only $30 \%$. A detailed study on the relationship between gender and land tenure in two rural communities in the Mekong and Red River Deltas of Scott at el (2009) shows a similar finding although the study also finds out that land distribution appears to be more equitable among households in Can Tho Province than those in the North. Therefore, gender equal access to property rights still needs to be developed in order to facilitate starting and running business for Vietnamese women entrepreneurs.

\section{Decrees}

In Article 9 of Decree 88, it is obligatory that the Ministry of Planning and Investment (MPI) offer training for staff working in the business and registration service. What needs to focus on is that according to the survey of UNIDO (2010), female entrepreneurs felt that they had less chance to start their own business. Therefore, it is necessary that the MPI contain the content of gender sensitivity trainings along with the aforementioned contents.

Due to the lack of concentration in Enterprise Law, in Article 5 of Decree 56, it is stated that assistance programme is given priority for two types of small and medium enterprises: those that are run by women, and those that provide employment opportunities for a vast number of female employees. In addition, Article 7 from the same Decree regulates the financial assistance, consultancy and training small and medium enterprises despite no gender separation, namely male and female-run enterprises. Likewise, it is not apparent as to whether this Article succeeds the prioritisation in Article 5. If it does, then it should clarify the foundation for female priority. Furthermore, what Article 7 lacks is the clarity of the responsible agency for managing and operation the training support for human resources. This could lead to confusion, for instance, pursuant to Article 13, the MPI is the focal agency. However, the MPI must seek request for the Ministry of Finance, which takes responsibility for balancing and arranging the budget for training.

Article 17 of the same Decree provides for the participation and contracts associated with the public services. Nonetheless, it does not state specifically whether women are encouraged or women-owned enterprises should be given more priority when it comes to tender calls. 
Circular 05 succeeding Decree 88 adds regulations the mechanisms of business transactions between enterprises on registration or taxation that are not fully covered in previous documents. In Article III.1, it is commended that through information transmission process such as fax or the Internet will pave the way for women who even lack educational qualifications, or face time and location-related obstacles.

Decree 108 has a similar problem as the Investment Law that it supports, which is the failure of recognising women involved in investing and entrepreneurial activities. Decree 108 determines domains and provinces which are eligible for special investment incentives. The fact that those incentives focus on scientific-oriented investment activities like technology or mechanics may probably prevent women from starting with small businesses and those engaging in feminised sectors. Instead, the participation of women in technical area should be built as an incentive, for instance, allocating a mandatory position for women in the field, or combined with the encouragement of women in this domain through education-related regulations.

\section{Implications and Recommendations for Further Study}

\subsection{Implications}

It is undeniable that women entrepreneurship has made significant contribution to the development of the socio-economy of Vietnam. The proportion of women participating in the formal economy has risen dramatically, mostly through private enterprises (83\%) and $26 \%$ of them work as head of the enterprises (UNDP, 2014). However, as aforementioned, given the fact that Vietnamese tradition has still favoured men over women and the legal framework still lacks reference to female entrepreneurs, this report will suggest some recommendations for the encouragement of the field of women entrepreneurs.

\section{Policy-oriented recommendations}

We suggest some policy-related implications for supporting women entrepreneurship in Vietnam. First the policy-makers should remove gradually gender discrimination at work, from governmental offices to business organisations, in which women are given more decision-making roles. The male vs. female ration for any decision-making roles at all political levels (provincial, district and community levels) as well as in organisations, and promulgate punitive measures for those that violate have to be ensured. 
The Government should implement specific hiring, training, promotion policies to have at least a certain proportion of women as senior or leading positions in government and the Party (30\%). Furthermore, the Parliament should regular review the legal system to evaluate the impact of presently legislation system on gender equality in general and female entrepreneurship in particular as to whether this comes up to the goals set in advance. If not, there should be amendments to increase the encouragement for women. In addition, the revision should be carried out in tandem with the update with the swiftly changing situation.

It is recommended that the policymakers should develop activities and models for the growth of businesses, concentrating on mainstream gender equality and increase the data on gender equality that is related to women entrepreneurship. Moreover, training programmes should be implemented within established enterprises that give preferences to women, such as short-term courses focusing on soft skills such as foreign language, consultancy, business administration, action plan development and so forth. Besides, long-term courses can be added with the collaboration of local companies to allow learners to take part in on-the-job training and gain hands-on practical experience. The curricula can be tailored by the government or the Ministry of Education and Training to fulfil the demand of the market.

As mentioned above, the Land Law 2013 has made a significant progress in supporting land ownership of women and this facilitates the procedure for women in seeking financial assistance from banks to start-up their own businesses. However, women still experience difficulties in seeking further funding further credit funds to start-up their own businesses and remain their business without hypothecating their real estate assets. Therefore, we propose that the Government should implementing investment fund and encourage venture funds to support women with capital needed for entrepreneurial activity.

\section{Mind-set change}

Overall, the rise in awareness of both men and women play an equally important role in changing the old tradition of Vietnam that has been an obstacle for women entrepreneurship for long. That is, decision making, property rights and inheritance, which have been traditionally linked to men, should be shared equally with women and similarly regarding domestic tasks should be carried out by men also. 
Although in Vietnam legally land rights are equal for men and women but in practice husbands have been put as the main registrant in land use right certificates, then wives are dependent on their husbands in using land as deposit for start-up. This can be improved by creating a campaign raising awareness of both genders on the essential role of joint land ownership; giving priority, assisting, and fast-track land registration applications that must have both the husband and wife's names; encouraging giving inheritance associated with land rights to female members of the family.

Domestic responsibilities should be shared between men and women. This can be seen as an obstacle for women who want to pursue an independent business. The government can help by designing campaigns for equality in male and female responsibility in childcare and household assignments. Besides, the infrastructure for childcare services and kindergartens can be improved, which can assist in child-support for children and save time for working families. Companies should pave the way for female participation by providing childcare facilities for their staff.

\subsection{Recommendations for Further Study}

This report on women entrepreneurship confirms the growing importance of women entrepreneurship in the socio-economic growth of Vietnam. What have been found through the report is that while the rate of women entrepreneurship is similar to that of men, they are most likely to operate smaller-scale and more vulnerable enterprises compared to their male counterparts. Also, in terms of management and decision-making roles, along with educational and employment opportunities, women are outweighed by men. In addition, future studies should identify the different impacts of opportunity and necessity entrepreneurship to the economic development in the context of Vietnam, and demonstrate the entrepreneurial motivation of Vietnamese women who is working in rural areas.

Besides, Vietnamese females have to face a number of challenges to engage in entrepreneurial activity. The reasons for that include the Confucian-influenced tradition and social norms, as well as the incomplete legal framework.

Given the summary above, it is clear that there are still room for future researchers to focus on the improvement for women entrepreneurship in Vietnam. Among the critical queries, some of the topics that can be explored, for example the impact of "Doi Moi" on the lives of women entrepreneurs, as well as opportunities and challenges associated with them 
in this period; the need for the development of statistical data on gender equality and women entrepreneurship; the incentive for women to start up and run businesses themselves; key lessons learned from other countries to apply for the practice of Vietnam; and the solutions for constraints that Vietnamese female entrepreneurs have been encountered.

\section{Conclusion}

This paper has provided insights into the current status of Vietnamese women entrepreneurs and barriers and obstacles they face in doing business. The issues of traditions and institutions that influence on Vietnamese women entrepreneurship have been analysed clearly. Regarding the institutional implications, we proposed policy-oriented recommendations and recommended some tradition changes in doing business and new law issues which may help policy makers build a support system for the development of women entrepreneurship. In view of the summary above, apparently there are rooms for future scholars to study on the improvement for women entrepreneurship in Vietnam. 


\section{REFERENCES}

Acs, Z. \& Varga, A. (2005) 'Entrepreneurship, agglomeration and technological change', Small Business Economics, 24, 323---334.

Avin, R.M \& Kinney, L.P (2014). Trends in Female Entrepreneurship in Vietnam Preliminary paper presented at the 23th Annual Conference on Feminist Economics sponsored by IAFFE, University of Ghana, Accra, Ghana, June 27-29, 2014.

Avin, R.-M., \& Kinney, L. P. (2014) 'Trends in Women entrepreneurship in Vietnam', 23 ${ }^{\text {rd }}$ Annual Conference on Feminist Economics, Ghana: 27 - 29 June.

Bruton, G. D., Ahlstrom, D., \& Obloj, K. (2008). Entrepreneurship in emerging economies: where are we today and where should the research go in the future. Entrepreneurship: Theory and Practice, 32(1), 1-14.

Bunck, J. M. (1997) Women and Post Cold War Socialism: the cases of Cuba and Vietnam, 7th Annual Meeting, Association for the Study of Cuban Economy, University of Miami, Knight Center, Hyatt Hotel, August 7-9 1997

Central Population and Housing Census Steering Committee (2010), The 2009 Vietnam Population and Housing Census: Completed Results, Statistical Publishing House, available at: http://vietnam.unfpa.org/webdav/site/vietnam/shared/Census\%20publications/3_Co mpleted-Results.pdf

Chari, M. D., \& Dixit, J. (2015). Business groups and entrepreneurship in developing countries after reforms. Journal Of Business Research,68, 1359-1366.

Djankov, S. , R. L. Porta , F. Lopez-de-Silanes and A. Schleifer (2002) The Regulation of Entry, Quarterly Journal of Economics CXVII (1): 1-37

Food and Agricultural Organisation and United Nations Development Programme (2002) 'Gender Differences in the Transitional Economy of Vietnam: Key Gender Findings Second Vietnam Living Standards Survey, 1997 - 1998'. Vietnam: Food and Agricultural Organisation and United Nations Development Programme. Available at: http://www.fao.org/docrep/005/ac685e/ac685e00.htm [Accessed 7 December 2015]. 
Fuentelsaz, L., González, C., Maícas, J., \& Montero, J. (2015). ‘How different formal institutions affect opportunity and necessity entrepreneurship'. Business Research Quarterly, 18(4), 246-258.

Gallup, J (2004) The wage labor market and inequality in Vietnam. In Economic growth, poverty, and household welfare in Vietnam edited by Paul Glewwe, Nisha Agrawal, and David Dollar. Washington, D.C.: The World Bank.

General Statistics Office of Vietnam (GSO) (2014), Population and employment Report 2014

Global Entrepreneurship Monitor. (2013). Vietnam report 2013. United Kingdom. Retrieved from: www.gemconsortium.org

Hampel-Milagrosa, A., Pham, H., Nguyen, Q., and Nguyen, T. (2010) 'Gender-Related Obstacles to Vietnamese Women Entrepreneurs'. Vietnam: United Nations Industrial Development Organisation and Vietnam Chamber of Commerce and Industry. Available at: http://www.un.org.vn/en/publications/publications-byagency/doc details/294-gender-related-obstacles-to-vietnamese-womenentrepreneurs. html [Accessed 7 December 2015].

Hang, T.T.T. (2008), “Women's leadership in Vietnam: opportunities and challenges", Signs, Vol. 34 No. 1, pp. 16-21.

Hirschman, C. and V. M. Loi (1996) Family and Household Structure in Vietnam: Some glimpses from a recent survey, Pacific Affairs Vol 69 (No. 2 (Summer 1996)): 229-249

Hoang, B.T. (2010), “Rural employment and life: challenges to gender roles in Vietnam's agriculture at present", paper presented at the FAO-IFAD-ILO Workshop on Gaps, Trends and Current Research in Gender Dimensions of Agricultural and Rural Employment: Differentiated Pathways Out of Poverty Rome, 31 March-2 April 2009, available at: www.faoilo.org/fileadmin/user_upload/fao_ilo/pdf/Papers/16_march/Thinh_final.pdf

Hoang, C., Hoang, C.L.T.S, Nguyen, T.P.C, Ngo, T.P.L, Tran, T.N, Vu, T.L (2013), The women's access to land in contemporary Vietnam. UNDP Report 2013

Hoskisson, R. E., Eden, L., Lau, C.M., \&Wright, M. (2000). Strategy in emerging economies. Academy of Management Journal, 43(3), 249-267. 
ILO (2011) 'Creation of an enabling environment for women entrepreneur in Vietnam: Mainstreaming gender issues in government policy on enterprise development', Hanoi.

International Finance Corporation (2006) A National Survey of Women Business Owners in Vietnam. Joint survey with Gender and Entrepreneurship Markets (GEM) and the Mekong Private Sector Development Facility (MPDF), Washington, DC, IFC

International Labour Organisation (2007) 'Women's Entrepreneurship Development in Vietnam'. Vietnam: International Labour Organisation.

International Labour Organization and the Ministry of Labour, Invalids and Social Affairs of Vietnam (2010), The Informal Economy in Vietnam, ILO/MOLISA, Hanoi.

Kibria, N. (1990) Power Patriarchy and Gender Conflict in the Vietnamese Immigrant Community, Gender and Society Vol 4 (No 1 (March 1990)): 9-24

Luke, N. , S. R. Schuler, B. T. T. Mai , P. V. Thien and T. H. Minh (2007) Exploring Couple Attributes and Attitudes and Marital Violence in Vietnam, New York, Sage Publications

McChesney, F. (1987) Rent extraction and rent creation in the economic theory of regulation, Journal of Legal Studies 16 de Soto, H. (2000) The Mystery of Capital: Why capitalism Triumphs in the west and Fails everywhere Else, New York, Basic Books

Minniti, M. (2010) 'Women entrepreneurship and Economic Activity', European Journal of Development Research, 22, pp. $294-312$.

Nguyen, B. (2011) 'The Changes of Women's Position: The Vietnam Case', International Journal of Innovative Interdisciplinary Research, 1, pp. $126-138$.

Nguyen, B. (2012) 'Abortion in Present Day Vietnam', International Journal of Academic Research in Business and Social Sciences, 2 (1), pp. $56-61$.

Nguyen, C., Frederick, H., \& Nguyen, H. (2014). Female entrepreneurship in rural Vietnam: An exploratory study. International Journal Of Gender And Entrepreneurship, 6(1), 50-67.

Nijssen, E.J. (2014), Entrepreneurial Marketing: An Effectual Approach, Routledge, New York, NY.

Raven, P., \& Le, Q. (2015). Teaching business skills to women: Impact of business training on women's microenterprise owners in Vietnam. International Journal Of Entrepreneurial Behaviour And Research, 21(4), 622-641. 
Rubio-Bañón, A., \& Esteban-Lloret, N. (2015). Research article: Cultural factors and gender role in female entrepreneurship. Suma De Negocios

Terrell, K., and Troilo, M. (2010) 'Values and Women entrepreneurship', International Journal of Gender and Entrepreneurship, 2 (3), pp. $260-286$.

Thanh, H.X., Anh, D.N. and Tacoli, C. (2005), "Livelihood diversification and rural-urban linkages in Vietnam's red river delta", Discussion Paper No. 193, International Food Policy Research Institute (IFPRI), available at: http://ideas.repec.org/p/fpr/fcnddp/193.html

The World Economic Forum (2015) 'The Global Gender Gap Report 2015'. Switzerland: The World Economic Forum. Available at: http://reports.weforum.org/global-gender-gapreport-2015/ [Accessed 8 December 2015].

Thi, L. (1995) Doi Moi and female workers: a case study of Ha Noi, in: V. M. Moghadam (ed.), Economic reforms, women's employment and social politics, Helsinki, World Institute for Development Research

Tien, P. N. (2010) Overarching view of Gender Equality in Vietnam", 2010, Conference on Commemoration of International Women's Day 2010, “Beijing + 15, Looking back, reaching forward, Gender Equality and Women Empowerment 15 years after the Fourth World Conference on Women, Ha Noi, 12 March 2010.

United Nations Development Programme (2012) 'Women's Representation in Leadership in Vietnam'. Vietnam: United Nations Development Programme.

United Nations Development Programme (2015) 'Human Development Report 2014'. USA: United Nations Development Programme. Available at: http://hdr.undp. org/en/content/human-development-report-2014 [Accessed 10 December 2015].

United Nations Industrial Development Organization (UNIDO). (2010). Gender related obstacles to Vietnamese Women Entrepreneurs. Vienna, Austria.

Vietnam Women Entrepreneurs Council (2007) Women's entrepreneurship development in Vietnam. International Labor Organization, Vietnam. 
Vuong, H., and Tran, D. (2009) 'The Cultural Dimensions of the Vietnamese Private Entrepreneurship', The IUP Journal of Entrepreneurship Development, 6 (3 \& 4), pp. 54 -78 .

VWEC (2007), Women's Entrepreneurship Development in Vietnam, Vietnam Chamber of Commerce and Industry (VCCI) and the International Labour Organization (ILO) Report, Vietnam Women Entrepreneurs Council, available at: www.ilo.org/wcmsp5/groups/public/@asia/@robangkok/documents/publication/wcms_100456.pdf

Williamson, O. (2000) 'The New Institutional Economics: Taking Stock, Looking ahead', Economic Literature, 38, pp. $595-693$.

World Bank (2011a) 'Vietnam Country Gender Assessment'. USA: World Bank. Available at: http://documents.worldbank.org/curated/en/2011/11/15470188/vietnam-countrygender-assessment [Accessed 7 December 2015].

World Bank (2011b). Vietnam development report 2012: Market economy for a middleincome Vietnam, Washington DC: The World Bank.

World Bank (2012), Vietnam Country Gender Assessment, World Bank Country Office, Hanoi World Bank (2015), World Bank Database, Available at: http://data.worldbank.org/country/vietnam [Accessed 9 December 2015].

World Development Indicators (WDI) (2012), The World Bank, Washington, DC.

Zhu, L., Kara, O., Chu, H.M.,Chu, A. (2015), 'Women entrepreneurship: Evidence from Vietnam', Journal of Business and Entrepreneurship, vol. 26, no. 3, pp. 103-128 